\title{
The Association Between Corporate Social Responsibility Activities And Earnings Quality: Evidence From Donations And Voluntary Issuance Of CSR Reports
}

Gyungmin Pyo, Ph.D. Candidate, Yonsei University, South Korea Ho-Young Lee, Ph.D., Professor, Yonsei University, South Korea

\begin{abstract}
This paper examines the association between the level of corporate social responsibility (CSR) activities and earnings quality with the level of donation expenses and the voluntary issuance of CSR reports filed with the Global Reporting Initiative (GRI) as proxies for CSR activities. Donation expenditures could be the most direct measure of managers' willingness to conduct CSR activities, while the voluntary issuance of CSR reports filed with GRI captures a direct signal of managers' willingness to conduct CSR activities. The results of this study provide evidence that firms active in CSR are likely to report earnings of a higher quality. More specifically, after controlling for firm-specific factors, we find that firms with more corporate donations have lower discretionary accruals and greater accounting conservatism. Furthermore, this negative relationship between donation and discretionary accruals is more pronounced when firms voluntarily issue CSR reports. Prior studies have focused on the association between financial performance and CSR activities of firms. However, managerial choices and signals on financial performance with voluntary CSR activities have not been specifically considered. This study adds to the existing literature on CSR by providing evidence of the role of CSR on earnings quality and helps academics and practitioners to understand the role of corporate donations and voluntary CSR disclosures in earnings quality.
\end{abstract}

Keywords: Accounting Conservatism; Corporate Social Responsibility Disclosure; Discretionary Accruals; Earnings Quality

\section{INTRODUCTION}

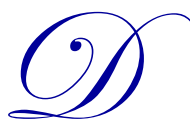

ue to the recent movement toward mutual benefits among companies and society, managers and investors are increasingly aware of the importance of social responsibility. Following this movement, some firms exert more effort in the area of corporate social responsibility (CSR, hereafter) activities than others. CSR activities may represent how managers view integrity. Some managers may have the incentive to use CSR activities strategically and opportunistically. In particular, managers who lack integrity may use CSR activities to compensate for their opportunistic behaviors. If so, CSR activities are positively associated with managers' opportunistic discretion over financial reporting. On the other hand, ethical and philanthropic managers tend to be actively involved in CSR activities as exemplary conduct (Paine, 1994). These managers are likely to provide more accurate and reliable financial reports. Thus, the net effect of CSR activities on earnings quality would be an empirical question and is of great interest to shareholders and policy makers.

Prior studies on CSR (e.g., Adams and McNicholas, 2007; Carroll, 1999; Dhaliwal et al., 2012; Kim et al., 2012; Magness, 2006, Orij, 2010) discuss the theoretical background of ethical behavior by firms. According to the stakeholder hypothesis, firms' decisions over monetary donations are heavily influenced by the interests of customers, employers, managers, governments, local communities and stockholders (Carroll, 1999; Freeman, 2010; 
Garriga and Mele, 2004). Collectively, these stakeholders' influence on firms' decisions over CSR activities represent the stakeholders' overall philanthropic view (Bentham, 1996; Carroll, 1999).

Lev et al. (2010) argue that firms may conduct CSR activities to develop their reputations because they believe a good reputation leads to increased sales. Johnson (1966) reports that firms in a monopolistically competitive market use charitable contributions as a means of gaining a strategic advantage over their competitors. Dhaliwal et al. (2012) report that CSR disclosures affect analysts' behavior in a more favorable way. Hobson and Kachelmeier (2005) suggest that managers may have an incentive to misuse CSR disclosures to compensate for poor quality of earnings. Paine (1994), however, suggests that firms are encouraged to display more ethical conduct to prevent behavior that damages the firm's value. Using the stakeholder hypothesis, Jones (1995) presents that firms have an incentive to demonstrate their philanthropic and ethical behavior when they run their business with integrity. Such firms are more likely to participate in CSR activities and to provide reliable financial statements.

To test whether CSR activities are driven by integrity or opportunistic motivation, we examine the association between earnings quality and the level of corporate donations and/or the voluntary issuance of CSR reports. To examine whether CSR activities are associated with the quality of earnings, we use two voluntary CSR activities: donation expenditures (Card et al., 2010) and the voluntary issuance of CSR reports (Dhaliwal et al., 2011). We use discretionary accruals (Dechow et al., 1995; Jones, 1991; Kothari et al., 2005) and accounting conservatism (Givoly and Hayn, 2000; Penman and Zhang, 2002) as proxies for the earnings quality of firms with donations and the voluntary issuance of CSR reports filed with the Global Reporting Initiative (GRI, hereafter). ${ }^{1}$

After controlling for firm-specific factors, we find evidence that firms active in CSR activities by means of monetary donations have lower discretionary accruals and greater accounting conservatism consistent with higher earnings quality. We also find some evidence that firms that both report more donation expenditures and issue voluntary CSR reports filed with GRI are even more likely to have higher earnings quality.

We believe that this study adds to the existing literature on CSR by providing further evidence of the role of CSR on earnings quality. This study helps academics and practitioners to understand the role of corporate donations and voluntary CSR disclosure in earnings quality. The results of this study also helps capital market participants by providing evidence that a firm's CSR activities are related to manager integrity in regards to financial reporting.

The rest of this paper is organized into five sections. The second section presents the study background and develops the hypotheses. The third section discusses the research method and the data selection procedures. The fourth section presents empirical results, and the last section concludes the study.

\section{BACKGROUND and HYPOTHESES}

\section{Corporate donations and voluntary issuance of CSR reports}

Hess et al. (2002) report that people have a more favorable impression of donations as forms of the provision of products, services, and cash as compared to volunteering by employees as a means of participating in communities. These provisions are recorded as donation expenses in firms' income statements. According to the stakeholder hypothesis, firms' decisions over CSR activities are heavily influenced by the interests of customers, employers, managers, governments, local communities, and stockholders (Bentham, 1996; Carroll, 1999; Freeman, 2010; Garriga and Mele, 2004; Orij, 2010). Thus, donations may reflect stakeholders' views of philanthropic activities (Jones, 1995).

\footnotetext{
1 The Global Reporting Initiative (GRI) is the most authoritative program of global standardization for corporate sustainability reporting endorsed by the United Nations Environmental Program (UNEP).
} 
Lev et al. (2010) suggest that firms may conduct CSR activities to develop their reputations, as they believe a good reputation results in increased sales. Dhaliwal et al. (2012) report that the disclosure of CSR activities complements financial disclosure and affects analysts' behavior in a more favorable way. One way to build a good reputation is to signal firms' contribution to society by publicizing their CSR activities in great detail.

As Paine (1994) suggests, managers in firms that voluntarily file CSR reports may have greater integrity over financial reporting or may show exemplary conduct by providing ethically sound financial report. Thus, firms that engage in voluntary CSR disclosures with GRI may provide higher quality of earnings. On the other hand, managers may have the incentive to misuse CSR disclosures to offset poor-quality earnings (Hobson and Kachelmeier, 2005). Managers may engage in CSR practices for personal benefit to pursue their self-interests or hide the true level of earnings management (Kim et al., 2012). Prior et al. (2008) state that managers may use CSR activities to obtain favorable coverage from the media and less scrutiny from investors and employees. CSR disclosure can also be used to mitigate the negative impact on firm value as a result of some corporate misconduct (Gray et al., 1995). When this opportunistic motivation dominates, firms who engage in voluntary CSR activities may have lower quality of earnings. To examine which motivation (either integrity or opportunistic) dominates, we test the association between donations and the voluntary issuance of CSR reports and earnings quality.

\section{Earnings quality}

Although a number of prior studies (e.g. Moore, 2001; Orlitzky, 2001; Torugsa et al., 2012) have focused on the relationship between CSR and financial performance, few studies have examined the role of CSR on earnings quality. Prior et al. (2008) examine whether firms use CSR strategically in financial reports. Using 593 firms included in the 2002-2004 SiRi Pro ${ }^{\mathrm{TM}}$ database, they find a positive relationship between discretionary accruals as computed based on the performance-matched model (Kothari et al., 2005) and a CSR score that is computed based on non-financial qualitative factors. Using the CSR index, Kim et al. (2012) find a negative relationship between earnings management ${ }^{2}$ and CSR scores ${ }^{3}$ in the U.S. However, Chih et al. (2008) find inconsistent evidence on earnings management by CSR firms. Reinhardt et al. (2008) report that there is a lack of evidence in literature of firms actually sacrificing their earnings goals through CSR activities. Unlike prior studies, we employ donation expenditures and the voluntary filing of CSR reports with GRI, which we believe are more direct or meaningful proxies that affect earnings quality measured as discretionary accruals and through accounting conservatism.

The FASB (Financial Accounting Standards Board, 1980) defines conservatism as a prudent reaction to recognize uncertainty and risks in business situations. Prior studies assume that conservatism uses the level of the asymmetric accounting method for a prudent recognition of uncertainty (Givoly and Hayn, 2000; Penman and Zhang, 2002; Watts, 2003a, 2003b). Watts (2003b) reports that the important aspect of conservatism is to reduce agency and other social costs. Conservatism has commonly been stated as a proxy for a person's integrity or ethics in psychology literature (Bogt et al., 2005). Taken together, in the world of business, conservatism would be the consequence of managers' integrity as regards financial reporting.

As CSR activities represent two different aspects of managers' motivation, we investigate the role of corporate donations and the voluntary filing of CSR reports with GRI on earnings quality. The above argument leads to our two hypotheses in null form, as follows:

H1: Ceteris paribus, the level donation expenditures is not associated with earnings quality.

H2: Ceteris paribus, the voluntary issuance of CSR reports filed with GRI is not associated with earnings quality.

\footnotetext{
${ }^{2}$ Kim et al. (2012) also use performance-matched discretionary accruals (Kothari et al., 2005) as a proxy for earnings management.

${ }^{3}$ Kim et al. (2012) use CSR scores measured as total strengths minus total concerns based on KLD's five social ratings.
} 
Firms with greater donation levels would be more aware of the value of integrity and may also desire to signal their devotion to integrity to the market. Alternatively, firms with greater donation levels may want to disguise agency problems as a form of operating inefficiency and/or misconduct by voluntarily publicizing their CSR activities. One way to signal or fake their integrity is to file voluntary reports with GRI. Thus, we investigate whether firms with voluntary issuance of CSR reports filed with GRI experience an incremental effect on the association between donations and earnings quality. The above argument leads to our third hypothesis.

H3: Ceteris paribus, the voluntary issuance of CSR reports filed with GRI affects the association between the level of donation expenditures and earnings quality.

If the first two hypotheses show a positive (negative) association between CSR activities and earnings quality, we predict that there would be a positive (negative) incremental effect caused by the voluntary filing of CSR reports with GRI on earnings quality. If donations and voluntary filing of CSR reports with GRI show different directional effects on earnings quality, the interaction effect of these two factors becomes ambiguous. The net effect depends on which factor dominates the effect.

\section{RESEARCH METHOD and DATA SELECTION}

To test the hypotheses, we use the amount of donation expenses scaled by total assets, an indicator representing the voluntary filing of CSR reports with GRI, and the interaction between the donation and the voluntary filing of CSR reports. In order to measure earnings quality, we utilize discretionary accruals and accounting conservatism. Both discretionary accruals and accounting conservatism can be used as proxies for earnings management and transparency, respectively (Kim et al., 2012; Watts, 2003b).

Firms donate money to various non-profit organizations and participate in community services as a part of their CSR efforts. The total donation amounts are disclosed in firms' income statements. Because firms are seeking profits, the donation amounts would represent economic sacrifices by firms reflecting the most direct intention or preference of management over CSR. In addition, firms have voluntarily issued their CSR reports on the GRI website. The Global Reporting Initiative (GRI) provides standardized and comprehensive guidelines for CSR activities and is well regarded as the most authoritative and definitive program of global standards for corporate sustainability reporting. The GRI was established by the Coalition for Environmentally Responsible Economies (CERES), a group endorsed by the United Nations Environmental Program (UNEP) (see Willis (2003) for details).

\section{Earnings quality}

We use discretionary accruals $(D A s)$ as a proxy for the quality of financial reporting, earnings management. $D A s$ are subject to estimation errors. Thus, this study utilizes both the modified-Jones DAs (MJDA) model as suggested in Dechow et al. (1995) and the performance-matched DAs (PMDA) model suggested in Kothari et al. (2005). DAs are computed as equation (1) as used in Kothari et al. (2005) and as equation (2), which is used in Dechow et al. (1995).

$$
\begin{aligned}
& \frac{T A_{i t}}{A_{i t-1}}=\alpha_{0}+\alpha_{1} \frac{1}{A_{i t-1}}+\alpha_{2} \frac{\Delta R E V_{i t}-\Delta A R_{i t}}{A_{i t-1}}+\alpha_{3} \frac{P P E_{i t}}{A_{i t-1}}+\alpha_{4} R O A_{i t-1}+\varepsilon_{i t} . \\
& \frac{T A_{i t}}{A_{i t-1}}=\alpha_{0} \frac{1}{A_{i t-1}}+\alpha_{1} \frac{\Delta R E V_{i t}-\Delta A R_{i t}}{A_{i t-1}}+\alpha_{2} \frac{P P E_{i t}}{A_{i t-1}}+\varepsilon_{i t} .
\end{aligned}
$$

where,

$T A=$ total accruals (net income - cash flow from operations) in year $\mathrm{t}$ for firm $\mathrm{i}$; 
$A=$ total assets in year $\mathrm{t}-1$;

$\triangle R E V=$ the difference between revenues in year $\mathrm{t}$ and in year $\mathrm{t}-1$;

$\triangle A R=$ the difference between accounts receivable in year $\mathrm{t}$ and in year $\mathrm{t}-1$;

$P P E^{4}=$ net depreciable property, plant, and equipment in year t;

$R O A=$ a return on assets in year $\mathrm{t}-1 ;$

$P M D A$ = estimated residuals from model (1);

$M J D A$ = estimated residuals from model (2).

\section{Accounting conservatism}

Watts (2003a) states that conservative accounting plays an important role in improving information quality for investors. Penman and Zhang (2002) suggest a conservatism index, C-Score, which indicates that more conservative firms may have more reserves relative to net operating assets or may choose accounting methods that result in low net operating assets relative to estimated reserves. We use two methods to compute accounting conservatism. First, as in Penman and Zhang (2002), we use balance sheet items for estimating accounting conservatism (CONS_PENMAN) with both estimated reserves $(E R)$ and net operating income (NOA). Second, as in Givoly and Hayn (2000), we use the accumulation of non-operating accruals (CONS_GIVOLY). We utilize these two measures to test the role of donation on accounting conservatism.

CONS_PENMAN $N_{i t}=E R_{i t} / N O A_{i t}$.

where,

CONS_PENMAN = an accounting conservatism measure which utilizes Penman and Zhang's (2002) approach;

$E R=$ the sum of depreciation expenses, amortization expenses, bad debt expenses, $\mathrm{R} \& \mathrm{D}$ expenses, and advertising expenses;

$N O A=$ the sum of equity and financial obligations, including short-term borrowings, the current portion of longterm liabilities, long-term bonds, long-term borrowings, and capital lease liabilities less financial assets including short-term securities, short-term loans, and short-term financial instruments;

CONS_GIVOLY $Y_{i t}=(-1)$ Non Operating Accruals it $_{\text {it }} / A_{i t}$.

where,

CONS_GIVOLY = an accounting conservatism measure which utilizes Givoly and Hayn's (2000) approach;

Non-Operating Accruals = total accruals excluding depreciation $\left(T A \_G I V O L Y\right)$ less operating accruals (OA);

TA_GIVOLY = NI + DEP - OCF;

$O A=\Delta \mathrm{AR}+\Delta \mathrm{INV}+\Delta \mathrm{PREP}-\triangle \mathrm{AP}-\Delta \mathrm{TAXP}$

$N I=$ net income;

$D E P=$ depreciation expenses;

$O C F=$ cash flows from operations;

$\triangle A R=$ the difference between accounts receivable in year $\mathrm{t}$ and in year $\mathrm{t}-1$;

$\triangle I N V=$ the difference between inventories in year $\mathrm{t}$ and in year $\mathrm{t}-1$;

$\triangle P R E P=$ the difference between prepaid expenses in year $\mathrm{t}$ and in year $\mathrm{t}-1$;

$\triangle A P=$ the difference between accounts payable in year $\mathrm{t}$ and in year $\mathrm{t}-1$;

$\triangle T A X P=$ the difference between taxes payable in year $\mathrm{t}$ and in year $\mathrm{t}-1$;

$A=$ total assets in year $\mathrm{t}$.

${ }^{4}$ Consistent with Culvenor et al. (1999), PPE excludes land and construction in progress. 


\section{Research model}

As in prior studies (Dhaliwal et al., 2011, 2012; Kim et al., 2012), we expect that corporate donations and the filing of CSR reports with GRI are associated with financial reporting quality in model (5). We use the following model to test the three hypotheses:

$$
\begin{aligned}
& D A(\text { or CONS })_{i t}=\beta_{0}+\beta_{1} D_{O N A T_{i t}}+\beta_{2} D_{-} C S R_{i t}+\beta_{3} D O N A T * D_{-} C S R_{i t}+\beta_{4} S I Z E_{i t}+\beta_{5} L_{E V}+\beta_{6} G R W_{i t}+\beta_{7} R O A_{i t} \\
& +\beta_{8} \text { BIG }_{i t}+\beta_{9} \text { SWITCH }_{i t}+\beta_{10} \text { OPINION }_{i t}+\beta_{11} \text { INVREC }_{i t}+\beta_{12} \text { LOSS }_{i t}+\beta_{13} \text { PTA }(\text { or PCONS })_{i t}+\sum I N D \& Y E A R+\varepsilon_{i t} .
\end{aligned}
$$

where,

$D A=P M D A$ or $M J D A$ from equation (1) and (2);

$D O N A T=$ level of computed donation expenses scaled by total assets in year $\mathrm{t}$;

$D \_C S R=1$ if a firm voluntarily issues CSR reports filed with GRI, and 0 otherwise;

CONS $=$ CONS_PENMAN or CONS_GIVOLY from equation (3) and (4);

$S I Z E=$ the natural $\log$ of total assets;

$L E V=$ leverage as total debt scaled by total assets;

$G R W=$ sales changes scaled by prior sales;

$R O A=$ net income scaled by total assets;

$B I G=1$ if the auditor is a Big 4 auditor, and 0 otherwise;

$S W I T C H=1$ if the auditor has changed, and 0 otherwise;

$O P I N I O N=1$ if the auditor's opinion is an unqualified opinion, and 0 otherwise;

$I N V R E C=$ the sum of inventory and accounts receivable scaled by total assets;

$L O S S=1$ if net income is less than zero, and 0 otherwise;

$P T A=$ the previous total accruals scaled by previous total assets;

$P C O N S=$ CONS_PENMAN or CONS_GIVOLY in the previous year;

$I N D$ and $Y E A R=$ dummies representing two-digit SIC industries and years.

Consistent with prior studies (e.g., Dechow et al., 1995; Givoly and Hayn, 2000; Jones, 1991; Kothari et al., 2005; Penman and Zhang, 2002), earnings quality is measured through the level of discretionary accruals and conservatism. We include the interaction term DONAT and D_CSR, as firms with increased DONAT and voluntary CSR filings are expected to choose more/less conservative accounting methods and lower/higher earnings management than others.

As in prior studies (DeFond and Jiambalvo, 1993, 1994; Francis et al., 1999, Reynolds and Francis, 2001; Simunic, 1980), we expect that firms of a smaller size, greater leverage, a lower growth rate, higher returns, more inventory and accounts receivable, and negative income are likely to manage earnings through discretionary accruals and to provide financial reports in a less conservative way. Firms with non-Big 4 auditors, new auditors, and qualified opinions may engage in earnings management and less conservatism (Palmrose, 1988; DeFond and Subramanyam, 1998; Reynolds and Francis, 2001; Francis, 2004).

Based on prior research, several control variables are added. SIZE may reflect the effects from omitted variables on earnings quality (Becker et al. 1998). $L E V$ may capture managers' opportunistic behaviors pertaining to earnings quality, as managers may manage earnings to avoid violations of debt covenants (DeFond and Jiambalvo, 1994). Ahmed et al. (2002) report a negative relationship between accruals and GRW or ROA. Penman and Zhang (2002) suggest that conservatism decreases the accounting rate of return. Together, we expect that $G R W$ and $R O A$ are positively related to discretionary accruals and are negatively related to accounting conservatism. As in DeFond and Subramanyam (1998), auditors, who are concerned with litigation risk, may decrease discretionary accruals or increase the level of conservatism. BIG and OPINION are expected to increase an auditor's litigation exposure and are therefore negatively related to discretionary accruals and positively related to conservatism. We expect that SWITCH shows an opposite relationship to BIG and OPINION, consistent with hope by managers (Ahmed et al., 2002). INVREC may show the same negative direction as $G R W$ and $R O A$, as growing and more profitable firms are prone to have greater inventories and/or accounts receivable (Ahmed et al., 2002; Simunic, 1980). The effect of 
LOSS on earnings quality is controversial. As in Becker et al. (1998), financial distress leads to reduced earnings for contractual renegotiations, whereas DeFond and Park (1997) argue that managers with poor performance have an incentive to increase income earnings management in order to reduce the threat of being dismissed.

Table 1

Sample Descriptions

\begin{tabular}{|c|c|c|c|c|}
\hline \multicolumn{5}{|l|}{ Panel A. Sample Selection Criteria 2004-2010 } \\
\hline Sample selection & & $D A$ & \multicolumn{2}{|c|}{ CONS } \\
\hline All firm-year observations from the Korea Stock Exchange (KSE) & & 5,495 & \multicolumn{2}{|c|}{5,495} \\
\hline (Less) Financial service & & $(609)$ & \multicolumn{2}{|c|}{$(609)$} \\
\hline (Less) Firms with insufficient financial data & & $(494)$ & \multicolumn{2}{|c|}{$(435)$} \\
\hline (Less) Firms that do not have December fiscal year-end & & $(152)$ & \multicolumn{2}{|c|}{$(152)$} \\
\hline (Less) Firms in industries with less than ten firms & & $\underline{(42)}$ & \multicolumn{2}{|c|}{$(42)$} \\
\hline Final Sample Size & & $\underline{4,198}$ & \multicolumn{2}{|c|}{$\underline{4,257}$} \\
\hline Panel B. Samples by year & \multicolumn{2}{|c|}{$D A$} & \multicolumn{2}{|c|}{ CONS } \\
\hline Year & Firms & $\%$ & Firms & $\%$ \\
\hline 2004 & 581 & 13.84 & 587 & 13.79 \\
\hline 2005 & 588 & 14.01 & 593 & 13.93 \\
\hline 2006 & 592 & 14.10 & 596 & 14.00 \\
\hline 2007 & 595 & 14.17 & 606 & 14.24 \\
\hline 2008 & 605 & 14.41 & 613 & 14.40 \\
\hline 2009 & 612 & 14.58 & 627 & 14.73 \\
\hline 2010 & $\underline{625}$ & $\underline{14.89}$ & $\underline{635}$ & $\underline{14.92}$ \\
\hline Total & $\underline{4,198}$ & $\underline{100}$ & $\underline{4,257}$ & $\underline{100}$ \\
\hline \multirow[t]{2}{*}{ Panel C. Samples by industries } & \multicolumn{2}{|c|}{$D A$} & \multicolumn{2}{|c|}{ CONS } \\
\hline & Firms & $\%$ & Firms & $\%$ \\
\hline Food, Beverages, Tobacco Products & 252 & 6.00 & 254 & 5.97 \\
\hline Wearing apparel, Wood, and Pulp Products & 347 & 8.27 & 351 & 8.25 \\
\hline Cokes and Chemical Products & 555 & 13.22 & 565 & 13.27 \\
\hline Medicinal Chemicals & 244 & 5.81 & 245 & 5.76 \\
\hline Non-metallic Mineral and Metal Products & 512 & 12.20 & 515 & 12.10 \\
\hline Electronic Components and Precision Instruments & 419 & 9.98 & 423 & 9.94 \\
\hline Other manufacturing & 527 & 12.55 & 536 & 12.59 \\
\hline Electricity, Gas, Construction, Real estate activities & 371 & 8.84 & 372 & 8.74 \\
\hline Sale of Motor Vehicles and Parts, and Transportation & 358 & 8.53 & 364 & 8.55 \\
\hline Information and Communications & 105 & 2.50 & 105 & 2.47 \\
\hline Wholesale Trade, and Other service activities & $\underline{508}$ & $\underline{12.10}$ & $\underline{527}$ & $\underline{12.38}$ \\
\hline Total & $\underline{4, \overline{198}}$ & $\underline{100}$ & $\underline{4,257}$ & $\underline{100}$ \\
\hline
\end{tabular}

\section{Data selection}

As presented in Table 1, Panel A, the sample used in this study consists of firms listed on the Korea Stock Exchange (KSE) ${ }^{5}$ from 2004 to 2010. We exclude firms in financial service industries, those with insufficient financial data and non-December fiscal year-end firms, as well as those with fewer than ten observations within a respective industry. Panels B and C of Table 1 present firm-year and firm-industry distributions showing that year or industry cluster is not a serious concern. Financial data are extracted from the KIS-VALUE ${ }^{6}$ database, and the CSR reports are obtained from the Global Reporting Initiative (GRI) website.

5 The KSE had a market capitalization of around 1.2 trillion USD as of the end of 2011. As of 2011, the market capitalization is ranked seventeenth in the world (refer to http://www.world-exchanges.org).

${ }^{6}$ The KIS-VALUE database in Korea provides both financial and stock market data for firms listed on the Korea Stock Exchange and KOSDAQ markets, equivalent to COMPUSTAT and CRSP in the U.S. 
Table 2

Descriptive Statistics

\begin{tabular}{|c|c|c|c|c|c|c|c|}
\hline \multicolumn{8}{|c|}{ Panel A. $D A$ models $(\mathrm{N}=4,198)$} \\
\hline & MEAN & STD & Min & Q1 & Median & Q3 & Max \\
\hline PMDA & 0.0001 & $\overline{0.0920}$ & -0.3591 & -0.0448 & 0.0003 & 0.0455 & 0.3366 \\
\hline MJDA & 0.0043 & 0.0974 & -0.3775 & -0.0401 & 0.0044 & 0.0503 & 0.4050 \\
\hline DONAT & 0.0011 & 0.0022 & 0.0000 & 0.0000 & 0.0002 & 0.0011 & 0.0126 \\
\hline D.CSR & 0.0264 & 0.1605 & 0 & 0 & 0 & 0 & 1 \\
\hline SIZE & 26.4377 & 1.4836 & 23.5517 & 25.3759 & 26.1499 & 27.2904 & 30.5910 \\
\hline$L E V$ & 0.4457 & 0.1923 & 0.0737 & 0.3027 & 0.4516 & 0.5844 & 0.9683 \\
\hline GRW & 0.1204 & 0.3431 & -0.6954 & -0.0195 & 0.0803 & 0.1943 & 2.5837 \\
\hline $\boldsymbol{R O A}$ & 0.0349 & 0.0863 & -0.4114 & 0.0107 & 0.0415 & 0.0767 & 0.2489 \\
\hline$B I G$ & 0.6901 & 0.4625 & 0 & 0 & 1 & 1 & 1 \\
\hline SWITCH & 0.2032 & 0.4024 & 0 & 0 & 0 & 0 & 1 \\
\hline OPINION & 0.9983 & 0.0408 & 0 & 1 & 1 & 1 & 1 \\
\hline INVREC & 0.2733 & 0.1543 & 0.0000 & 0.1583 & 0.2648 & 0.3782 & 0.6646 \\
\hline LOSS & 0.1677 & 0.3736 & 0 & 0 & 0 & 0 & 1 \\
\hline PTA & -0.0182 & 0.0995 & -0.3891 & -0.0637 & -0.0187 & 0.0297 & 0.3338 \\
\hline
\end{tabular}

Panel B. CONS models $(\mathrm{N}=4,257)$

\begin{tabular}{|c|c|c|c|c|c|c|c|}
\hline & MEAN & STD & Min & Q1 & Median & Q3 & Max \\
\hline CONS_PENMAN & 0.0792 & 0.0813 & 0.0009 & 0.0327 & 0.0568 & 0.0956 & 0.5692 \\
\hline CONS_GIVOLY & -0.0056 & 0.0801 & -0.3908 & -0.0288 & -0.0034 & 0.0189 & 0.3494 \\
\hline DONAT & 0.0011 & 0.0022 & 0.0000 & 0.0000 & 0.0002 & 0.0011 & 0.0126 \\
\hline D.CSR & 0.0263 & 0.1601 & 0 & 0 & 0 & 0 & 1 \\
\hline SIZE & 26.4367 & 1.4831 & 23.4713 & 25.3784 & 26.1501 & 27.2865 & 30.5733 \\
\hline$L E V$ & 0.4453 & 0.1930 & 0.0627 & 0.3015 & 0.4516 & 0.5846 & 0.9677 \\
\hline GRW & 0.1322 & 0.3744 & -0.7090 & -0.0185 & 0.0818 & 0.1993 & 2.5837 \\
\hline $\boldsymbol{R O A}$ & 0.0352 & 0.0862 & -0.4114 & 0.0107 & 0.0415 & 0.0769 & 0.2558 \\
\hline$B I G$ & 0.6911 & 0.4621 & 0 & 0 & 1 & 1 & 1 \\
\hline SWITCH & 0.2023 & 0.4017 & 0 & 0 & 0 & 0 & 1 \\
\hline OPINION & 0.9984 & 0.0405 & 0 & 1 & 1 & 1 & 1 \\
\hline INVREC & 0.2728 & 0.1549 & 0.0000 & 0.1576 & 0.2647 & 0.3783 & 0.6696 \\
\hline LOSS & 0.1675 & 0.3735 & 0 & 0 & 0 & 0 & 1 \\
\hline PCONS_PENMAN & 0.0821 & 0.0822 & 0.0009 & 0.0349 & 0.0599 & 0.0991 & 0.5692 \\
\hline PCONS_GIVOLY & -0.0016 & 0.0835 & -0.3908 & -0.0270 & -0.0018 & 0.0211 & 0.3494 \\
\hline
\end{tabular}


Table 3

Pearson Correlation Matrix

\begin{tabular}{|c|c|c|c|c|c|c|c|c|c|c|c|c|}
\hline \multicolumn{13}{|c|}{ Panel A. $D A$ models $(\mathrm{N}=4,198)$} \\
\hline & 2 & 3 & 4 & 5 & 6 & 7 & 8 & 9 & 10 & 11 & 12 & 13 \\
\hline \multirow[t]{2}{*}{ 1.DONAT } & 0.0240 & 0.0237 & 0.0800 & -0.1321 & 0.0289 & 0.2115 & 0.1010 & -0.0288 & -0.0007 & 0.0397 & -0.1467 & -0.0110 \\
\hline & 0.1206 & 0.1249 & $<.0001$ & $<.0001$ & 0.0611 & $<.0001$ & $<.0001$ & 0.0621 & 0.9639 & 0.0102 & $<.0001$ & 0.4783 \\
\hline \multirow[t]{2}{*}{ 2.D.CSR } & & 0.9983 & 0.3533 & 0.0240 & -0.0049 & 0.0333 & 0.1018 & -0.0205 & 0.0067 & -0.1212 & -0.0144 & -0.0362 \\
\hline & & $<.0001$ & $<.0001$ & 0.1199 & 0.7492 & 0.0310 & $<.0001$ & 0.1843 & 0.6626 & $<.0001$ & 0.3521 & 0.0191 \\
\hline \multirow[t]{2}{*}{ 3.PAGE } & & & 0.3529 & 0.0236 & -0.0055 & 0.0338 & 0.1022 & -0.0199 & 0.0067 & -0.1209 & -0.0143 & -0.0366 \\
\hline & & & $<.0001$ & 0.1263 & 0.7240 & 0.0283 & $<.0001$ & 0.1978 & 0.6632 & $<.0001$ & 0.3532 & 0.0178 \\
\hline \multirow[t]{2}{*}{ 4.SIZE } & & & & 0.1715 & 0.0211 & 0.1842 & 0.3586 & -0.0323 & 0.0143 & -0.3593 & -0.1661 & 0.0102 \\
\hline & & & & $<.0001$ & 0.1724 & $<.0001$ & $<.0001$ & 0.0367 & 0.3535 & $<.0001$ & $<.0001$ & 0.5077 \\
\hline \multirow[t]{2}{*}{ 5.LEV } & & & & & 0.0815 & -0.3122 & 0.0444 & 0.0003 & -0.0579 & 0.1236 & 0.2206 & -0.1008 \\
\hline & & & & & $<.0001$ & $<.0001$ & 0.0041 & 0.9845 & 0.0002 & $<.0001$ & $<.0001$ & $<.0001$ \\
\hline \multirow[t]{2}{*}{ 6.GRW } & & & & & & 0.1259 & 0.0059 & 0.0213 & 0.0098 & 0.0528 & -0.0855 & -0.0458 \\
\hline & & & & & & $<.0001$ & 0.7032 & 0.1685 & 0.5250 & 0.0006 & $<.0001$ & 0.0030 \\
\hline \multirow[t]{2}{*}{ 7.ROA } & & & & & & & 0.1367 & -0.0131 & 0.1328 & 0.0315 & -0.6893 & 0.0753 \\
\hline & & & & & & & $<.0001$ & 0.3973 & $<.0001$ & 0.0415 & $<.0001$ & $<.0001$ \\
\hline \multirow[t]{2}{*}{$8 . B I G$} & & & & & & & & -0.0255 & 0.0113 & -0.1200 & -0.0829 & -0.0031 \\
\hline & & & & & & & & 0.0987 & 0.4638 & $<.0001$ & $<.0001$ & 0.8431 \\
\hline \multirow[t]{2}{*}{ 9.SWITCH } & & & & & & & & & 0.0206 & 0.0049 & -0.0017 & -0.0112 \\
\hline & & & & & & & & & 0.1812 & 0.7502 & 0.9144 & 0.4682 \\
\hline \multirow[t]{2}{*}{ 10.OPINION } & & & & & & & & & & 0.0164 & -0.0754 & -0.0095 \\
\hline & & & & & & & & & & 0.2882 & $<.0001$ & 0.5374 \\
\hline \multirow[t]{2}{*}{ 11.INVREC } & & & & & & & & & & & -0.0296 & 0.0920 \\
\hline & & & & & & & & & & & 0.0550 & $<.0001$ \\
\hline \multirow[t]{2}{*}{ 12.LOSS } & & & & & & & & & & & & -0.0614 \\
\hline & & & & & & & & & & & & $<.0001$ \\
\hline
\end{tabular}




\begin{tabular}{|c|c|c|c|c|c|c|c|c|c|c|c|c|c|}
\hline & 2 & 3 & 4 & 5 & 6 & 7 & 8 & 9 & 10 & 11 & 12 & 13 & 14 \\
\hline \multirow[t]{2}{*}{ 1.DONAT } & 0.0243 & 0.0241 & 0.0804 & -0.1280 & 0.0280 & 0.2116 & 0.1013 & -0.0281 & -0.0007 & 0.0415 & -0.1468 & 0.1458 & 0.0297 \\
\hline & 0.1128 & 0.1164 & $<.0001$ & $<.0001$ & 0.0681 & $<.0001$ & $<.0001$ & 0.0665 & 0.9623 & 0.0068 & $<.0001$ & $<.0001$ & 0.0524 \\
\hline \multirow[t]{2}{*}{ 2.D.CSR } & & 0.9982 & 0.3503 & 0.0225 & -0.0066 & 0.0341 & 0.1014 & -0.0207 & 0.0067 & -0.1199 & -0.0148 & 0.0605 & -0.0013 \\
\hline & & $<.0001$ & $<.0001$ & 0.1430 & 0.6656 & 0.0263 & $<.0001$ & 0.1779 & 0.6635 & $<.0001$ & 0.3352 & $<.0001$ & 0.9314 \\
\hline \multirow[t]{2}{*}{ 3.PAGE } & & & 0.3497 & 0.0218 & -0.0067 & 0.0348 & 0.1018 & -0.0201 & 0.0067 & -0.1196 & -0.0148 & 0.0614 & -0.0010 \\
\hline & & & $<.0001$ & 0.1545 & 0.6634 & 0.0232 & $<.0001$ & 0.1893 & 0.6640 & $<.0001$ & 0.3340 & $<.0001$ & 0.9470 \\
\hline \multirow[t]{2}{*}{ 4.SIZE } & & & & 0.1715 & 0.0264 & 0.1815 & 0.3598 & -0.0318 & 0.0145 & -0.3573 & -0.1665 & -0.0486 & -0.0593 \\
\hline & & & & $<.0001$ & 0.0851 & $<.0001$ & $<.0001$ & 0.0380 & 0.3436 & $<.0001$ & $<.0001$ & 0.0015 & 0.0001 \\
\hline \multirow[t]{2}{*}{ 5.LEV } & & & & & 0.0786 & -0.3121 & 0.0464 & 0.0006 & -0.0573 & 0.1287 & 0.2225 & 0.0670 & 0.1035 \\
\hline & & & & & $<.0001$ & $<.0001$ & 0.0025 & 0.9690 & 0.0002 & $<.0001$ & $<.0001$ & $<.0001$ & $<.0001$ \\
\hline \multirow[t]{2}{*}{ 6.GRW } & & & & & & 0.1239 & 0.0107 & 0.0052 & 0.0102 & 0.0382 & -0.0822 & -0.0164 & 0.1234 \\
\hline & & & & & & $<.0001$ & 0.4862 & 0.7331 & 0.5054 & 0.0127 & $<.0001$ & 0.2842 & $<.0001$ \\
\hline \multirow[t]{2}{*}{ 7.ROA } & & & & & & & 0.1332 & -0.0141 & 0.1322 & 0.0306 & -0.6874 & -0.0449 & -0.0449 \\
\hline & & & & & & & $<.0001$ & 0.3573 & $<.0001$ & 0.0457 & $<.0001$ & 0.0034 & 0.0034 \\
\hline \multirow[t]{2}{*}{ 8.BIG } & & & & & & & & -0.0257 & 0.0113 & -0.1189 & -0.0818 & 0.0242 & -0.0366 \\
\hline & & & & & & & & 0.0942 & 0.4603 & $<.0001$ & $<.0001$ & 0.1146 & 0.0170 \\
\hline \multirow[t]{2}{*}{ 9.SWITCH } & & & & & & & & & 0.0204 & 0.0026 & -0.0019 & 0.0266 & -0.0141 \\
\hline & & & & & & & & & 0.1825 & 0.8664 & 0.9018 & 0.0832 & 0.3588 \\
\hline \multirow[t]{2}{*}{ 10.OPINION } & & & & & & & & & & 0.0161 & -0.0750 & -0.0399 & -0.0107 \\
\hline & & & & & & & & & & 0.2938 & $<.0001$ & 0.0093 & 0.4840 \\
\hline \multirow[t]{2}{*}{ 11.INVREC } & & & & & & & & & & & -0.0260 & -0.0101 & 0.1178 \\
\hline & & & & & & & & & & & 0.0904 & 0.5090 & $<.0001$ \\
\hline \multirow[t]{2}{*}{ 12.LOSS } & & & & & & & & & & & & 0.0445 & 0.0552 \\
\hline & & & & & & & & & & & & 0.0037 & 0.0003 \\
\hline 13.PCONS_PENMAN & & & & & & & & & & & & & - \\
\hline 14.PCONS_GIVOLY & & & & & & & & & & & & & - \\
\hline
\end{tabular}




\section{EMPIRICAL RESULTS}

\section{Descriptive statistics}

Table 2, Panel A and Panel B, presents descriptive statistics of the test and control variables. We winsorize variables with continuous values at the $1^{\text {st }}$ and the $99^{\text {th }}$ percentiles to control for the effects of extreme observations. The mean value of the performance-matched discretionary accruals (PMDA) is 0.0001 , while that of the modified Jones discretionary accruals $(M J D A)$ is 0.0043 , consistent with Kothari et al. (2005), who also report a smaller $P M D A$ value than the MJDA value. Regarding accounting conservatism, the mean value of CONS_PENMAN is 0.0792 that is greater than the mean value of CONS_GIVOLY (-0.0056). Big 4 auditors audit about 69 percent of firms, and about 20 percent of firms changed their auditors during the sample period for both the $D A$ (Panel A) and CONS (Panel B) samples. About 0.2 percent of sample firms received a qualified opinion, and about 16.8 percent of firms experienced losses.

Table 3 reports the correlation matrix among the variables used in the empirical analyses. Table 3, Panel A, shows that the highest correlation is -0.6893 between ROA and LOSS. The correlation coefficients of the rest of the variables are not very high. Table 3, Panel B, also shows similar results in that the correlation coefficient between $R O A$ and LOSS is -0.6874 . The remaining variables are not highly correlated. ${ }^{7}$ The highest VIF value in any of the regression analyses is 2.2 in both models, indicating that multicollinearity is not a serious concern.

\section{Regression results}

Table 4 shows the empirical results of multivariate regression analyses to test three hypotheses. The $D A$ models show the relationship between donations and discretionary accruals. DONAT is significant and negatively associated with discretionary accruals in both the PMDA and MJDA models (significant at the 1 percent level). This result is consistent with Chih et al. (2008) and Kim et al. $(2012)^{8}$, indicating that managers' discretion over financial reporting decreases with the level of corporate donation. This result also suggests that firms with higher donation expenditures are less prone to engage in earnings management through discretionary accruals, rejecting H1. ${ }^{9}$ D_CSR is insignificant in both DA models, failing to find evidence of an association between the voluntary issuance of CSR reports and earnings quality.

The CONS models show a relationship between donation expenditure and accounting conservatism. DONAT is significant and positively associated with accounting conservatism in both the CONS_PENMAN and CONS_GIVOLY models (significant at the 1 percent level), indicating that managers' discretion over accounting conservatism increases with the level of corporate donation. As in the results from the DA models, D_CSR is statistically insignificant in both CONS models, failing to find evidence of an association between the voluntary issuance of CSR reports and earnings quality.

The interaction term $D O N A T^{*} D \_C S R$ is negative and significant at the 1 percent level in both the PMDA and MJDA models. These results suggest that the significantly negative association between DONAT and PMDA (and MJDA) becomes stronger when firms voluntarily issue CSR reports with GRI. This result indicates that firms voluntarily filing CSR reports enhance the association between donations and earnings quality. However, the interaction terms $D O N A T^{*} D \_C S R$ in both the CONS_PENMAN and CONS_GIVOLY models are statistically insignificant.

${ }^{7}$ Dropping either ROA or LOSS does not change our conclusion and provides qualitatively identical results.

${ }^{8}$ Chih et al. (2008) report a relationship between CSR and earnings management (EM). However, they use FTSE4Good Indexes as a proxy for CSR activities rather than the level of donation expenses, and the measures of EM are based on Bhattacharya et al. (2003) and Leuz et al. (2003). Kim et al. (2012) use a combined score of KLD's five social ratings based on surveys, financial statements, and articles by KLD Research and Analytics as a proxy of the level of CSR activities and use Domini 400 Social Index as a proxy for a dummy variable of CSR activities.

${ }^{9}$ When we use the Generalized Least Squares (GLS) model to mitigate heteroscadacity and auto-correlation problems discussed in LeClair and Gordon (2000), the results for the main variables by GLS regression are not qualitatively different from the results by OLS. 
Consistent with prior studies (e.g., Ahmed et al., 2002; DeFond and Jiambalvo, 1994; Reynolds and Francis, 2001; among others), LEV, ROA and INVREC are positively related to discretionary accruals, suggesting that firms with higher leverage, higher returns on assets, and more inventory and accounts receivable experience a greater managers' discretion over financial reporting, while SIZE is negatively associated with discretionary accruals. $L E V$, GRW, ROA, and LOSS are significant in both the CONS_PENMAN and CONS_GIVOLY models at least at the 10 percent level. BIG, SWITCH, and PCONS_PENMAN are significant only in the CONS_PENMAN model, while SIZE, OPINION, INVREC, and PCONS_GIVOLY are significant only in the CONS_GIVOLY model.

Table 4

The Relationship between Donations or CSR Reports and Earnings Quality

\begin{tabular}{|c|c|c|c|c|}
\hline \multirow{2}{*}{ Variables } & \multicolumn{2}{|c|}{$D A$ models } & \multicolumn{2}{|c|}{ CONS models } \\
\hline & PMDA & $\overline{M J D A}$ & CONS.PENMAN & CONS_GIVOLY \\
\hline Intercept & $\begin{array}{r}0.0153 \\
(0.34)\end{array}$ & $\begin{array}{r}0.0587 \\
(1.27)\end{array}$ & $\begin{array}{c}0.0718 \\
(2.44)^{* *}\end{array}$ & $\begin{array}{r}-0.0433 \\
-(1.18)\end{array}$ \\
\hline DONAT & $\begin{array}{l}-2.9305 \\
-(4.40)^{* * * *}\end{array}$ & $\begin{array}{l}-3.4728 \\
-(5.09)^{* * *}\end{array}$ & $\begin{array}{l}3.2333 \\
(7.43)^{* * * *}\end{array}$ & $\begin{array}{l}2.7124 \\
(4.97)^{* * *}\end{array}$ \\
\hline D.CSR & $\begin{array}{r}0.0150 \\
(1.31)\end{array}$ & $\begin{array}{r}0.0041 \\
(0.35)\end{array}$ & $\begin{array}{r}0.0059 \\
(0.79)\end{array}$ & $\begin{array}{r}0.0012 \\
(0.13)\end{array}$ \\
\hline DONAT*D.CSR & $\begin{array}{l}-16.2498 \\
-(3.26)^{* * *}\end{array}$ & $\begin{array}{l}-13.7039 \\
-(2.68)^{* * *}\end{array}$ & $\begin{array}{r}4.7105 \\
(1.45)\end{array}$ & $\begin{array}{r}2.0569 \\
(0.50)\end{array}$ \\
\hline SIZE & $\begin{array}{l}-0.0022 \\
-(1.83)^{*}\end{array}$ & $\begin{array}{l}-0.0023 \\
-(1.91)^{*}\end{array}$ & $\begin{array}{r}-0.0003 \\
-(0.36)\end{array}$ & $\begin{array}{l}0.0040 \\
(4.14)^{* * *}\end{array}$ \\
\hline$L E V$ & $\begin{array}{l}0.0233 \\
(2.80)^{* * * *}\end{array}$ & $\begin{array}{r}0.0108 \\
(1.27)\end{array}$ & $\begin{array}{l}0.0090 \\
(1.67)^{*}\end{array}$ & $\begin{array}{l}-0.0151 \\
-(2.22)^{* *}\end{array}$ \\
\hline GRW & $\begin{array}{r}0.0041 \\
(1.01)\end{array}$ & $\begin{array}{r}0.0026 \\
(0.62)\end{array}$ & ${ }^{0.0086}{ }^{* * * * *}$ & $\begin{array}{l}0.0170 \\
(5.64)^{* * * *}\end{array}$ \\
\hline ROA & $\begin{array}{l}0.4064 \\
(17.67)^{* * * *}\end{array}$ & $\begin{array}{l}0.5073 \\
(21.52)^{* * * *}\end{array}$ & $\begin{array}{l}-0.2158 \\
-(14.50)^{* * * *}\end{array}$ & $\begin{array}{l}-0.4584 \\
-(24.42)^{* * *}\end{array}$ \\
\hline$B I G$ & $\begin{array}{r}-0.0020 \\
-(0.63)\end{array}$ & $\begin{array}{r}-0.0049 \\
-(1.52)\end{array}$ & $\begin{array}{l}0.0041 \\
(1.99)^{* *}\end{array}$ & $\begin{array}{r}-0.0016 \\
-(0.63)\end{array}$ \\
\hline SWITCH & $\begin{array}{r}0.0013 \\
(0.38)\end{array}$ & $\begin{array}{r}0.0013 \\
(0.39)\end{array}$ & $\begin{array}{l}-0.0054 \\
-(2.49)^{* *}\end{array}$ & $\begin{array}{r}0.0017 \\
(0.63)\end{array}$ \\
\hline OPINION & $\begin{array}{r}0.0038 \\
(0.12)\end{array}$ & $\begin{array}{r}-0.0200 \\
-(0.59)\end{array}$ & $\begin{array}{r}-0.0275 \\
-(1.27)\end{array}$ & $\begin{array}{l}-0.0677 \\
-(2.49)^{* *}\end{array}$ \\
\hline INVREC & $\begin{array}{l}0.0500 \\
(4.56)^{* * *}\end{array}$ & $\begin{array}{l}0.0427 \\
(3.80)^{* * * *}\end{array}$ & $\begin{array}{r}0.0100 \\
(1.42)\end{array}$ & $\begin{array}{l}0.0804 \\
(9.06)^{* * *}\end{array}$ \\
\hline LOSS & $\begin{array}{r}0.0051 \\
(1.01)\end{array}$ & $\begin{array}{r}0.0077 \\
(1.50)\end{array}$ & $\begin{array}{l}-0.0089 \\
-(2.73)^{* * *}\end{array}$ & $\begin{array}{l}-0.0119 \\
-(2.91)^{* * *}\end{array}$ \\
\hline PTA & $\begin{array}{r}-0.0095 \\
-(0.69)\end{array}$ & $\begin{array}{l}0.0609 \\
(4.29)^{* * *}\end{array}$ & - & - \\
\hline PCONS.PENMAN & - & - & $\begin{array}{l}0.6314 \\
(56.53)^{* * * *}\end{array}$ & - \\
\hline PCONS.GIVOLY & - & - & - & $\begin{array}{l}0.0634 \\
(4.71)^{* * *}\end{array}$ \\
\hline IND/YEAR & Included & Included & Included & Included \\
\hline F-value & $21.07^{* * *}$ & $32.49^{* * *}$ & $160.41^{* * *}$ & $40.67^{* * * *}$ \\
\hline Adj R square & 0.1218 & 0.1787 & 0.5207 & 0.2128 \\
\hline Max VIF & 2.23 & 2.23 & 2.21 & 2.21 \\
\hline $\mathbf{N}$ & 4,198 & 4,198 & 4,257 & 4,257 \\
\hline $\begin{array}{l}\text { Notes: ***, **, and } \\
P M D A \text { is performan } \\
\text { CONS.PENMAN de } \\
\text { conservatism measu } \\
\text { firm discloses CSR } \\
\text { log of total assets, } L \\
\text { income scaled by to } \\
\text { otherwise, OPINIOI } \\
\text { accounts receivable } \\
\text { scaled by prior total } \\
\text { GIVOLY, IND/YEAK }\end{array}$ & $\begin{array}{l}\text { icance at the } 1,5 \text {, an } \\
\text { retionary accruals } \mathrm{fr} \\
\text { rvatism measures } \\
1 \text { Hayn }(2000) \text { from } \\
\text { nd } 0 \text { otherwise, } D O I \\
\text { is total debt scaled } \\
1 \text { if the auditor is a } \\
\text { itor's opinion is an } \\
\text { issets, LOSS is } 1 \text { if } \\
\text { PENMAN is the pre } \\
\text { able for each indust }\end{array}$ & $\begin{array}{l}\text { ercent levels, resp } \\
\text { q.(1), MJDA is the } \\
\text { man and Zhang } \\
\text {, DONAT is the do } \\
\text { OCSR is an interac } \\
\text { l assets, GRW der } \\
\text { auditor and } 0 \text { othe } \\
\text { alified opinion and } \\
\text { come is less than } \\
\text { year's CONS.PENI } \\
\text { each year. }\end{array}$ & $\begin{array}{l}\text { tively. } \\
\text { hodified Jones' discretion } \\
002 \text { ) from Eq.(3), CON } \\
\text { ation amount scaled by to } \\
\text { on term for DONAT and } \\
\text { es sales changes scaled } \\
\text { ise, SWITCH is } 1 \text { if the } \\
\text { otherwise, INVREC is } \\
\text { ro and } 0 \text { otherwise, PTA } \\
A N, P C O N S \text { GIVOLY is }\end{array}$ & $\begin{array}{l}\text { y accruals from Eq.(2), } \\
\text { GIVOLY represents the } \\
1 \text { assets, D.CSR is } 1 \text { if a } \\
C S R, S I Z E \text { is the natural } \\
\text { prior sales, ROA is net } \\
\text { litor was changed and } 0 \\
\text { sum of inventory and } \\
\text { the prior total accruals } \\
\text { previous year's CONS }\end{array}$ \\
\hline
\end{tabular}


In summary, we find that firms incurring greater expenses for donations exercise lower management discretion and greater accounting conservatism over financial reporting. This result suggests that managers who donate higher percentage of their firms' total assets may have a greater level of corporate integrity, which is consistent with management's philanthropic viewpoint and the stakeholder hypothesis (Bentham, 1996; Carroll, 1999). There is evidence that this phenomenon is more pronounced when firms voluntarily issue CSR reports filed with GRI.

\section{Abnormal corporate donation}

Amato and Amato (2007) find that the level of corporate donation is significantly related to the firm size, advertising expenditures, and ROA. To control for endogenous effects of donation expenditures (DONAT) by firmspecific factors, we compute residuals as abnormal donations (ABNDONAT) from equation (6).

$$
D O N A T_{i t}=\alpha_{0}+\alpha_{1} A D V_{i t}+\alpha_{2} R O A_{i t}+\alpha_{3} S I Z E_{i t}+\alpha_{4} S I Z E_{i t}^{2}+\alpha_{5} S I Z E_{i t}^{3}+\sum I N D+\varepsilon_{i t} .
$$

where,

$D O N A T=$ donation expenses scaled by total assets in year $\mathrm{t}$;

$A D V=$ advertising expenses scaled by total assets in year $\mathrm{t}$;

$R O A=$ net income scaled by total assets in year $\mathrm{t}$;

$S I Z E=$ the natural log of total assets in year $\mathrm{t}$;

$I N D=$ dummies representing two-digit SIC industries.

We then replace DONAT with ABNDONAT in model (5). Table 5 reports the results of the additional analyses using abnormal donations instead of the level of donation. ABNDONAT ${ }^{10}$ denotes the residuals between DONAT and the estimated DONAT, and ABNDONAT is significant in the PMDA (t-value: -3.65 , sig. at the 1 percent level), MJDA (t-value: -4.51), CONS_PENMAN (t-value: 4.79), and CONS_GIVOLY (t-value: 4.20) models. These findings suggest that firms with greater additional donation expenditures than expected are prone to engage less in earnings management through discretionary accruals and to choose conservative accounting methods, rejecting $\mathrm{H} 1$. The filing of voluntary CSR reports, $D_{-} C S R$, shows a coefficient consistent with expectations. However, the result is significant only with the MJDA (at the 10 percent level) and CONS_PENMAN (at the 5 percent level) models. The interaction term $A B N D O N A T^{*} D_{-} C S R$ is consistently related to earnings quality in both DA and CONS models, as predicted, but we fail to find statistically significant evidence of an incremental effect of the filing of CSR reports on the association between $A B N D O N A T$ and earnings quality.

From the results of the additional regression analyses, we also provide generally consistent evidence of the notion that firms with more active CSR activities are associated with higher levels of earnings quality than others.

\section{Level of voluntary CSR reporting}

This study also investigates whether the volume of CSR disclosure is associated with earnings quality. Following Dhaliwal et al. (2012), we use the number of pages as a proxy for the level of CSR effort. Table 6 shows additional analyses of the volume of voluntary CSR reporting. ${ }^{11}$ To compare the level of CSR reporting, we replace D_CSR with PAGE, which represents the quantitative level of the CSR reporting effort. If the number of pages in voluntary CSR reports indicates the managers' eager willingness to disclose details of CSR activities, we expect that the effect of donation on earnings quality in each model is increased with an increase in the level of CSR reporting

10 To compute ABNDONAT, we utilized the generalize least squares (GLS) which avoids heteroscadacity. The results with ABNDONAT in OLS regression are not qualitatively different from results in GLS.

11 When we conduct the analyses with $A B N D O N A T$ and $P A G E$, which are not reported here, we find results similar to those with ABNDONAT and D_CSR. 
effort. These findings suggest that firms that strive to disclose CSR activities are less prone to engage in earnings management through discretionary accruals and to choose conservative accounting, rejecting H1.

Table 5

The Relationship between ABNDONAT or CSR Reports and Earnings Quality

\begin{tabular}{|c|c|c|c|c|}
\hline \multirow{2}{*}{ Variables } & \multicolumn{2}{|c|}{$D A$ models } & \multicolumn{2}{|c|}{ CONS models } \\
\hline & $P M D A$ & $M J D A$ & CONS_PENMAN & CONS_GIVOLY \\
\hline \multirow[t]{2}{*}{ Intercept } & 0.0226 & 0.0677 & 0.0626 & -0.0492 \\
\hline & $(0.50)$ & $(1.47)$ & $(2.12)^{* * *}$ & $-(1.33)$ \\
\hline \multirow[t]{2}{*}{$A B N D O N A T$} & -2.5354 & -3.2105 & 2.1591 & 2.3798 \\
\hline & $-(3.65)^{* * *}$ & $-(4.51)^{* * *}$ & $(4.79)^{* * *}$ & $(4.20)^{* * *}$ \\
\hline \multirow[t]{2}{*}{ D.CSR } & -0.0081 & -0.0154 & 0.0123 & 0.0042 \\
\hline & $-(0.90)$ & $-(1.67)^{*}$ & $(2.10)^{* *}$ & $(0.57)$ \\
\hline \multirow[t]{2}{*}{ ABNDONAT* D.CSR } & -5.0918 & -2.8217 & 0.0778 & 1.6972 \\
\hline & $-(0.81)$ & $-(0.44)$ & $(0.02)$ & $(0.33)$ \\
\hline \multirow[t]{2}{*}{ SIZE } & -0.0026 & -0.0028 & 0.0002 & 0.0043 \\
\hline & $-(2.22)^{* *}$ & $-(2.35)^{* *}$ & $(0.28)$ & $(4.50)^{* * * *}$ \\
\hline \multirow[t]{2}{*}{$L E V$} & 0.0252 & 0.0125 & 0.0068 & -0.0156 \\
\hline & $(3.02)^{* * * *}$ & $(1.46)$ & $(1.26)$ & $-(2.30)^{* *}$ \\
\hline \multirow[t]{2}{*}{$G R W$} & 0.0042 & 0.0027 & 0.0087 & 0.0170 \\
\hline & $(1.05)$ & $(0.66)$ & $(3.63)^{* * *}$ & $(5.62)^{\text {**** }}$ \\
\hline \multirow[t]{2}{*}{$\mathrm{ROA}$} & 0.3938 & 0.4928 & -0.2029 & -0.4478 \\
\hline & $(17.19)^{* * *}$ & $(21.00)^{* * *}$ & $-(13.66)^{* * *}$ & $-(23.98)^{* * * *}$ \\
\hline \multirow[t]{2}{*}{$B I G$} & -0.0021 & -0.0050 & 0.0043 & -0.0015 \\
\hline & $-(0.65)$ & $-(1.54)$ & $(2.11)^{* * *}$ & $-(0.57)$ \\
\hline \multirow[t]{2}{*}{ SWITCH } & 0.0013 & 0.0013 & -0.0056 & 0.0017 \\
\hline & $(0.39)$ & $(0.39)$ & $-(2.57)^{* *}$ & $(0.63)$ \\
\hline \multirow[t]{2}{*}{ OPINION } & 0.0045 & -0.0197 & -0.0279 & -0.0675 \\
\hline & $(0.14)$ & $-(0.58)$ & $-(1.29)$ & $-(2.48)^{* *}$ \\
\hline \multirow[t]{2}{*}{ INVREC } & 0.0487 & 0.0415 & 0.0116 & 0.0809 \\
\hline & $(4.43)^{* * * *}$ & $(3.68)^{* * * *}$ & (1.64) & $(9.11)^{* * * *}$ \\
\hline \multirow[t]{2}{*}{ LOSS } & 0.0046 & 0.0072 & -0.0085 & -0.0116 \\
\hline & $(0.93)$ & $(1.39)$ & $-(2.60)^{* * *}$ & $-(2.84)^{* * *}$ \\
\hline \multirow[t]{2}{*}{ PTA } & -0.0079 & 0.0623 & - & - \\
\hline & $-(0.57)$ & $(4.39)^{* * * *}$ & & \\
\hline PCONS_PENMAN & - & - & $\begin{array}{l}0.6392 \\
(57.35)^{* * * *}\end{array}$ & - \\
\hline PCONS_GIVOLY & - & - & - & $\begin{array}{l}0.0642 \\
(4.76)^{* * * *}\end{array}$ \\
\hline IND/ YEAR & Included & Included & Included & Included \\
\hline F-value & $20.35^{* * * *}$ & $31.88^{* * * *}$ & $160.41^{* * *}$ & $40.34^{\text {**** }}$ \\
\hline Adj R square & 0.1179 & 0.1758 & 0.5207 & 0.2114 \\
\hline Max VIF & 2.20 & 2.20 & 2.18 & 2.18 \\
\hline$\underline{\mathbf{N}}$ & 4,198 & 4,198 & 4,257 & 4,257 \\
\hline
\end{tabular}

Notes: $* * *, * *$, and $*$ represent significance at the 1,5 , and 10 percent levels, respectively.

ABNDONAT denotes the abnormal donation amount scaled by total assets from Eq.(5). Definitions of other variables are in table 4.

Table 6 shows results similar to those in Table 4 with $D \_C S R$. Consistent with the results of $D \_C S R, P A G E$ is not statistically significant in both the $D A$ and CONS models. The interaction term (DONAT*PAGE), however, is significantly associated with earnings quality in both the $P M D A$ and $M J D A$ models. Additional analyses confirm our findings in Table 4, showing that firms with active CSR, in terms of monetary donations and actively publicized activities, are more likely to have even higher earnings quality than firms without any active publication of CSR activities. 
Table 6

The Relationship between Donations or Volume of CSR Reports and Earnings Quality

\begin{tabular}{|c|c|c|c|c|}
\hline \multirow{2}{*}{ Variables } & \multicolumn{2}{|c|}{$D A$ models } & \multicolumn{2}{|c|}{ CONS models } \\
\hline & PMDA & $M J D A$ & CONS_PENMAN & CONS_GIVOLY \\
\hline \multirow[t]{2}{*}{ Intercept } & 0.0152 & 0.0587 & 0.0724 & -0.0423 \\
\hline & $(0.34)$ & $(1.28)$ & $(2.47)^{* *}$ & $-(1.15)$ \\
\hline \multirow[t]{2}{*}{ DONAT } & -2.9408 & -3.4817 & 3.2349 & 2.7149 \\
\hline & $-(4.41)^{* * *}$ & $-(5.10)^{* * *}$ & $(7.43)^{* * * *}$ & $(4.97)^{* * *}$ \\
\hline \multirow[t]{2}{*}{$P A G E$} & 0.0031 & 0.0007 & 0.0015 & 0.0006 \\
\hline & $(1.20)$ & $(0.27)$ & $(0.87)$ & $(0.26)$ \\
\hline \multirow[t]{2}{*}{ DONAT* PAGE } & -3.4940 & -2.9465 & 1.0503 & 0.4209 \\
\hline & $-(3.09)^{* * *}$ & $-(2.54)^{* *}$ & (1.42) & $(0.45)$ \\
\hline \multirow[t]{2}{*}{ SIZE } & -0.0022 & -0.0023 & -0.0003 & 0.0040 \\
\hline & $-(1.83)^{*}$ & $-(1.92)^{*}$ & $-(0.39)$ & $(4.11)^{* * *}$ \\
\hline \multirow[t]{2}{*}{$L E V$} & 0.0234 & 0.0109 & 0.0090 & -0.0150 \\
\hline & $(2.81)^{* * *}$ & $(1.28)$ & $(1.67)^{*}$ & $-(2.22)^{* *}$ \\
\hline \multirow[t]{2}{*}{$\boldsymbol{G R W}$} & 0.0041 & 0.0026 & 0.0086 & 0.0170 \\
\hline & $(1.02)$ & $(0.62)$ & $(3.62)^{* * *}$ & $(5.64)^{* * *}$ \\
\hline \multirow[t]{2}{*}{ ROA } & 0.4064 & 0.5073 & -0.2158 & -0.4584 \\
\hline & $(17.67)^{* * * *}$ & $(21.52)^{* * * *}$ & $-(14.50)^{* * *}$ & $-(24.42)^{* * *}$ \\
\hline \multirow[t]{2}{*}{$B I G$} & -0.0020 & -0.0049 & 0.0041 & -0.0016 \\
\hline & $-(0.63)$ & $-(1.52)$ & $(1.99)^{* *}$ & $-(0.63)$ \\
\hline \multirow[t]{2}{*}{ SWITCH } & 0.0013 & 0.0013 & -0.0054 & 0.0017 \\
\hline & $(0.38)$ & (0.39) & $-(2.50)^{* *}$ & $(0.63)$ \\
\hline \multirow[t]{2}{*}{ OPINION } & 0.0039 & -0.0200 & -0.0275 & -0.0677 \\
\hline & $(0.12)$ & $-(0.59)$ & $-(1.27)$ & $-(2.49)^{* *}$ \\
\hline \multirow[t]{2}{*}{ INVREC } & 0.0500 & 0.0427 & 0.0100 & 0.0804 \\
\hline & $(4.56)^{* * * *}$ & $(3.80)^{* * * *}$ & (1.42) & $(9.06)^{* * *}$ \\
\hline \multirow[t]{2}{*}{ LOSS } & 0.0051 & 0.0077 & -0.0089 & -0.0119 \\
\hline & (1.01) & $(1.49)$ & $-(2.74)^{* * *}$ & $-(2.92)^{* * *}$ \\
\hline \multirow[t]{2}{*}{$P T A$} & -0.0094 & 0.0609 & - & - \\
\hline & $-(0.68)$ & $(4.30)^{* * *}$ & & \\
\hline PCONS_PENMAN & - & - & $\begin{array}{l}0.6313 \\
(56.52)^{\text {**** }}\end{array}$ & - \\
\hline PCONS_GIVOLY & - & - & - & $\begin{array}{c}0.0634 \\
(4.71)^{* * *}\end{array}$ \\
\hline IND/YEAR & Included & Included & Included & Included \\
\hline F-value & $21.02^{* * * *}$ & $32.46^{* * *}$ & $160.44^{* * * *}$ & $40.67^{* * *}$ \\
\hline Adj R square & 0.1215 & 0.1786 & 0.5207 & 0.2128 \\
\hline Max VIF & 2.23 & 2.23 & 2.21 & 2.21 \\
\hline $\mathbf{N}$ & 4,198 & 4,198 & 4,257 & 4,257 \\
\hline
\end{tabular}

Notes: ***,**, and * represent significance at the 1,5 , and 10 percent levels, respectively.

$P A G E$ is the natural log of total pages of CSR reports. Definitions of other variables are in table 4.

\section{CONCLUSIONS}

This study examines whether corporate donations and the voluntary issuance of CSR reports are associated with earnings quality. High-quality earnings are the result of transparent and conservative accounting choices (Watts, 2003a). Donation expenditures could be the most direct and objective measure of managers' willingness to conduct CSR activities. This study also utilizes the filing of voluntary issuances of CSR reports with GRI because it is deemed to be a good proxy for managers' willingness to conduct CSR activities. After controlling for firm-specific factors, this study provides evidence that firms with higher levels of corporate donation have lower discretionary accruals and greater accounting conservatism. Furthermore, this study finds that the relationship between donations and earnings quality is more pronounced when firms voluntarily issue CSR reports filed with GRI. This study enables academics and practitioners to understand the role of corporate donations and voluntary CSR disclosure on earnings quality as proxied by managers' levels of discretion in regards to financial reporting and conservative accounting choices. 
This study adds to the existing CSR literature by providing additional evidence of the role of CSR activities on earnings quality. This study also helps capital market participants to improve their understanding of manager integrity and business ethics associated with CSR. Future studies may examine the effect of various characteristics of managers and/or governance characteristics on CSR activities and their decision-making activities.

\section{AUTHOR INFORMATION}

Gyungmin Pyo, Ph.D. Candidate, Yonsei University, School of Business, 50 Yonsei-ro, Seodaemun-gu, Seoul 120749, South Korea. E-mail: gyung@yonsei.ac.kr

Ho-Young Lee, Ph.D., Professor, Yonsei University, School of Business, 50 Yonsei-ro, Seodaemun-gu, Seoul 120749, South Korea. +82 22123 5484. E-mail: hylee@yonsei.ac.kr (Corresponding author)

\section{REFERENCES}

1. Adams, C. A. and McNicholas, P. (2007). Sustainability reporting accountability and organisational change. Accounting, Auditing \& Accountability Journal, 20(3) 382-402.

2. Ahmed, A. S., Billings, B. K., Morton, R. M. and Stanford-Harris, M. (2002). The Role of Accounting Conservatism in Mitigating Bondholder-Shareholder Conflicts over Dividend Policy and in Reducing Debt Costs. The Accounting Review, 77(4) 867-890.

3. Amato, L. H. and Amato, C. H. (2007). . The Effects of Firm Size and Industry on Corporate Giving. Journal of Business Ethics, 72(3) 229-241.

4. Bhattacharya, U., Daouk, H. and Welker, M. (2003). The World Price of Earnings Opacity. The Accounting Review, 78(3) 641-678.

5. Becker, C., DeFond, M., Jiambalvo, J. and Subramanyam, K. (1998). The effect of audit quality on earnings management. Contemporary Accounting Research, 15(1) 1-24.

6. Bentham, J. (1996). An Introduction to the Principles of Morals and Legislation. Clarendon, New York: Oxford University Press.

7. Bogt,T., Raaijmakers, Q. and Wel, F. (2005). Socialization and development of the work ethic among adolescents and young adults. Journal of Vocational Behavior, 66(3) 420-437.

8. Card, D., Hallock, K. and Moretti, E. (2010). The Geography of Giving: The Effect of Corporate Headquarters on Local Charities. Journal of Public Economics, 94(3) 222-234.

9. Carroll, B. A. (1999). Corporate Social Responsibility. Business \& Society, 38(3) 268-295.

10. Chih, H., Shen, C. and Kang, F. (2008). Corporate social responsibility, investor protection, and earnings management: Some international evidence. Journal of Business Ethics, 79(1) 179-198.

11. Culvenor, J, Godfrey, J. M. and Byrne, G. (1999). Modeling Total Accruals in an International Environment: The Impact of Alternative Measures of PPE. International Accounting, Auditing \& Taxation, 8(2) 289-313.

12. Dechow, P., Sloan, R. and Sweeney, A. (1995). Detecting earnings management. The Accounting Review, 70(2) 193-225.

13. DeFond, M. and Jiambalvo, J. (1993). Factors Related to Auditor-Client Disagreements over IncomeIncreasing Accounting Methods. Contemporary Accounting Research, 9(2) 415-431.

14. DeFond, M. and Jiambalvo, J. (1994). Debt covenant violation and manipulation of accruals. Journal of Accounting and Economics, 17(1) 145-176.

15. DeFond, M. L. and Park, C. W. (1997). Smoothing income in anticipation of future earnings. Journal of Accounting and Economics, 23(2) 115-139.

16. DeFond, M. L. and Subramanyam, K. R. (1998). Auditor changes and discretionary accruals. Journal of Accounting and Economics, 25 (1) 35-67.

17. Dhaliwal, D. S., Li, O. Z., Tsang, A. and Yang, Y. G. (2011). Voluntary Nonfinancial Disclosure and the Cost of Equity Capital: The Initiation of Corporate Social Responsibility Reporting. The Accounting Review, 86(1) 59-100.

18. Dhaliwal, D. S., Radhakrishnan, S., Tsang, A. and Yang, Y. G. (2012). Nonfinancial Disclosure and Analyst Forecast Accuracy: International Evidence on Corporate Social Responsibility Disclosure. The Accounting Review, 87(3) 723-759. 
19. Financial Accounting Standards Board. (1980). Statement of Financial Accounting Concepts No. 2. Retrieved from: http://www.fasb.org/jsp/FASB/Page/SectionPage\&cid=11761563 17989

20. Francis, J. R., Maydew, E. L. and Sparks, C. (1999). The Role of Big 6 Auditors in the Credible Reporting of Accruals. Auditing: A Journal of Practice \& Theory, 18(2) 17-34.

21. Francis, J. R. (2004). What Do We Know about Audit Quality?. The British Accounting Review, 36(4) 345368.

22. Freeman, R.E. (2010), Strategic Management: A Stakeholder Approach. New York: Cambridge University Press.

23. Garriga, E. and Mele, D. (2004). Corporate Social Responsibility Theories: Mapping the Territory. Journal of Business Ethics, 53(1) 51-71.

24. Givoly, D. and Hayn, C. (2000). The changing time-series properties of earnings, cash flows and accruals: Has financial reporting become more conservative?. Journal of Accounting and Economics, 29(3) 287-320.

25. Gray, R., Kouhy, R. and Lavers, S. (1995). Corporate Social and Environmental Reporting: A Review of the Literature and a Longitudinal Study of UK Disclosure. Accounting, Auditing and Accountability Journal, $8(2)$ 47-77.

26. Hess, D., Rogovsky, N. and Dunfee, T. W. (2002). The Next Wave of Corporate Community Involvement: Corporate Social Initiatives. California Management Review, 44(2) 110-125.

27. Hobson, J. L. and Kachelmeier, S. J. (2005). Strategic disclosure of risky prospects: A laboratory experiment. The Accounting Review, 80(3) 825-846.

28. Johnson, O. (1966). Corporate philanthropy: An analysis of corporate contributions. The Journal of Business, 39(4) 489-504.

29. Jones, J. J. (1991). Earnings management during import relief investigations. Journal of Accounting Research, 29(2) 193-228.

30. Jones, T. (1995). Instrumental Stakeholder Theory: A Synthesis of Ethics and Economics. The Academy of Management Review, 20(2) 404-437.

31. Kim, Y., Park, M. S. and Wier, B. (2012). Is Earnings Quality Associated with Corporate Social Responsibility?. The Accounting Review, 87(3) 761-796.

32. Kothari, S. P., Leone, A. and Wasley, C. (2005). Performance matched discretionary accrual measures. Journal of Accounting and Economics, 39(1) 163-197.

33. LeClair, M. S. and Gordon, K. (2000). Corporate Support for Artistic and Cultural Activities: What Determines the Distribution of Corporate Giving?. Journal of Cultural Economics, 24(3) 225-241.

34. Leuz, C., Nanda, D. and Wysocki, P. D. (2003). Earnings Management and Investor Protection: An International Comparison. Journal of Financial Economics, 69(3) 505-527.

35. Lev, B., Petrovits, C. and Radhakrishnan, S. (2010). Is doing good good for you? Yes, charitable contributions enhance revenue growth. Strategic Management Journal, 31(2) 182-200.

36. Magness, V. (2006). Strategic posture financial performance and environmental disclosure: An empirical test of legitimacy theory. Accounting, Auditing \& Accountability Journal, 19(4) 540-563.

37. Moore, G. (2001). Corporate Social and Financial Performance: An Investigation in the U.K. Supermarket Industry. Journal of Business Ethics, 34(3) 299-315.

38. Orij, R. (2010). Corporate social disclosures in the context of national cultures and stakeholder theory. Accounting, Auditing \& Accountability Journal, 23(7) 868-889.

39. Orlitzky, M. (2001). Does firm size confound the relationship between social performance and firm financial performance?. Journal of Business Ethics, 33(2) 167-180.

40. Palmrose. Z. (1988). An analysis of auditor litigation and audit service quality. The Accounting Review, 63(1) 55-73.

41. Paine, L. S. (1994). Managing for Organizational Integrity. Harvard Business Review, 72(2) 106-117.

42. Penman, S. and Zhang, X. (2002). Accounting conservatism, the quality of earnings, and stock returns. The Accounting Review, 77(2) 237-264.

43. Prior, D., Surroca, J. and Tribo, J. (2008). Are socially responsible managers really ethical? Exploring the relationship between earnings management and corporate social responsibility. Corporate Governance, 16(3) 160-177.

44. Reinhardt, F., Stavins, R. and Vietor, R. (2008). Corporate social responsibility through an economic lens. Review of Environmental Economics and Policy, 2(2) 219-239. 
45. Reynolds, J. and Francis, J. (2001). Does size matter? The influence of large clients on office-level auditor reporting decisions. Journal of Accounting and Economics, 30(3) 375-400.

46. Simunic, D. (1980). The pricing of audit services: Theory and evidence. Journal of Accounting Research, 18(1) 161-190.

47. Torugsa, N. A., O’Donohue, W. and Hecker, R. (2012). Capabilities, Proactive CSR and Financial Performance in SMEs: Empirical Evidence from an Australian Manufacturing Industry Sector. Journal of Business Ethics, 109(4) 483-500.

48. Watts, R. L. (2003a). Conservatism in accounting Part I: Explanations and implications. Accounting Horizons, 17(3) 207-221.

49. Watts, R. L. (2003b). Conservatism in accounting Part II: Evidence and research opportunities. Accounting Horizons, 17(4) 287-301.

50. Willis, A. (2003). The Role of the Global Reporting Initiative's Sustainability Reporting Guidelines in the Social Screening of Investments. Journal of Business Ethics, 43(3) 233-237. 